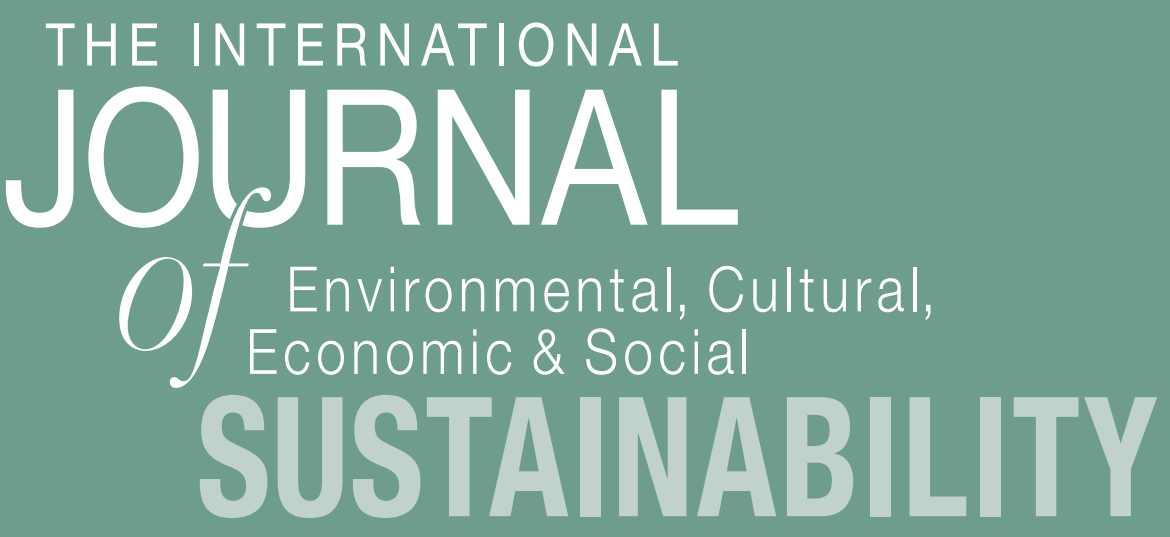

Volume 7 , Number 2

Lightweight Dividing Walls: Adaptation to Temperate Climates

Paulo Mendonca and Mónica Macieira 
THE INTERNATIONAL JOURNAL OF ENVIRONMENTAL, CULTURAL, ECONOMIC AND SOCIAL SUSTAINABILITY

http://www.Sustainability-Journal.com

First published in 2011 in Champaign, Illinois, USA

by Common Ground Publishing LLC

www.CommonGroundPublishing.com

ISSN: $1832-2077$

(C) 2011 (individual papers), the author(s)

(c) 2011 (selection and editorial matter) Common Ground

All rights reserved. Apart from fair dealing for the purposes of study, research, criticism or review as permitted under the applicable copyright legislation, no part of this work may be reproduced by any process without written permission from the publisher. For permissions and other inquiries, please contact

<cg-support@commongroundpublishing.com>.

THE INTERNATIONAL JOURNAL OF ENVIRONMENTAL, CULTURAL, ECONOMIC AND SOCIAL SUSTAINABILITY is peer-reviewed, supported by rigorous processes of criterion-referenced article ranking and qualitative commentary, ensuring that only intellectual work of the greatest substance and highest significance is published.

Typeset in Common Ground Markup Language using CGPublisher multichannel typesetting system

http://www.commongroundpublishing.com/software/ 


\title{
Lightweight Dividing Walls: Adaptation to Temperate Climates
}

\author{
Paulo Mendonca, University of Minho, Portugal \\ Mónica Macieira, University of Minho, Portugal
}

\begin{abstract}
This paper intends to prove that it is possible to use lightweight membranes on interior partition walls and on external façades, even in housing buildings at temperate climate regions, if their properties are well explored. The few material used, even less than conventional lightweight solutions - the most common is plasterboard with light steel frame structure - allow a lower specific embodied energy and other more favourable environmental impact indicators. Compared to conventional heavyweight solutions, such as hollow brick walls, lightweight membranes allow easier deconstruction/reuse. In the outer skin, architectural membranes can be used as passive or active systems, for heating (promoting greenhouse effect) and cooling (shading or even evaporative cooling). Lightweight materials are more viable to be used on invariably hot or cold climates, than on temperate climates, as in this context they present problems related with its low thermal storage capacity. However, the research of new architectural membrane materials, with passive and active behavior for thermal regulation, allows extending its possibilities to interior dividing partitions in order to fulfill contemporary demands of comfort. Active and/or passive systems can be used to regulate thermal gains - for example by radiant panels and/or evaporative cooling, but also to achieve thermal inertia. In pavements, thermal storage lightweight elements, using natural Phase Change Materials, were already studied and reported on previous studies from the first author. Examples of how these systems can also be applied to lightweight membrane dividing walls are presented in this paper, and some experimental research is now under course on test cell facilities existing in University of Minho, Guimarães.
\end{abstract}

Keywords: Solar Passive/Active Systems Integration, Lightweight Dividing Walls, Composites

\section{Introduction}

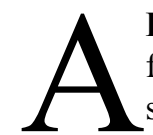

RCHITECTURAL MEMBRANES ARE nowadays used with competitive costs for covering big spans, but they can also be suitable for small size constructions, such as housing buildings [1].

The fact of being the lighter constructive solution for facades and coverings used in buildings and nowadays having a life span that exceeds 25 years makes architectural membranes extremely competitive in terms of deconstruction effectiveness, embodied energy, economic cost and durability, even in exterior applications, as presented by Mendonça [1], Miravete [2] and Ossola [3]. Besides that, membranes have now the advantage of being at the same time translucent, but weighting much less than other solutions, even glass, per square meter. Generally, membranes are translucent, but not transparent; they are in most cases composites with a textile based structure (such as polyester and fiberglass) with a polymeric covering, such as Polyvinyl chloride - PVC, Polytetrafluoroethylene - PTFE or Silicon [4].

The International Journal of Environmental, Cultural, Economic and Social Sustainability C $O M M O N$ Volume 7, Number 2, 2011, http://www.Sustainability-Journal.com, ISSN 1832-2077 